\title{
PERSEPSI MASYARAKAT DESA SETIAMEKAR TAMBUN SELATAN BEKASI TERHADAP DA'WAH MASJID WADHAH ABDURRAHMAN AL-BAHR PUSDIKLAT DEWAN DA'WAH
}

\author{
E-ISSN: 2721-7531 \\ bttp://jurnal-stidnatsir.ac.id/index.php/index \\ DOI: 10.38214/jurnalbinaummatstidnatsir.v3i02.89
}

Submitted: 30-11-2020 Reviewed: 08-12-2020 Published: 28-12-2020

\author{
Agus Samsono \\ agussamsono@stidnatsir.ac.id \\ STID Mobammad Natsir, Indonesia
}

Yoga Taufik Pratama

yogatpratama2019@gmail.com

STID Mobammad Natsir, Indonesia

\begin{abstract}
ABSTRAK
Tujuan penelitian: Untuk Mengukur Seberapa Besar Persepsi Masyarakat Desa Setiamekar Tambun dari Segi Penerimaan, pemahaman, dan Penilaian Terhadap Da'wah Masjid Wadhah Abdurrahman Al-Bahr Pusdiklat Dewan Da'wah. Metode yang digunakan dalam penelitian ini kuantitatif deskriptif. Variabel dalam penelitian ini hanya berjumlah satu variabel atau variabel tunggal, tidak melibatkan variabel lain yang bersifat mempengaruhi atau di pengaruhi. Adapun variabel tersebut adalah persepsi. Penelitian dilakukan di masyarakat desa setiamekar pada tahun 2019. Pengumpulan data penelitian ini menggunakan angket yang disebar pada masyarakat Desa Setiamekar. Kesimpulan dari penelitian ini yaitu; (1) Terdapat persepsi sangat positif dari segi penerimaan Masyarakat Desa Setiamekar terhadap Da'wah Masjid Wadhah Abdurrahman Al-Bahr Pusdiklat Dewan Da'wah dengan nilai skor 13.788, mean 4,28, nilai median 5,00, dan nilai modus 5. (2) Terdapat persepsi positif dari segi pemahaman Masyarakat Desa Setiamekar terhadap Da'wah Masjid Wadhah Abdurrahman Al-Bahr Pusdiklat Dewan Da'wah dengan skor 13.313, mean 4,1, nilai median 4,00, dan nilai modus 4. (3) Terdapat persepsi sangat positif dari segi penilaian Masyarakat Desa Setiamekar terhadap Da'wah Masjid Wadhah Abdurrahman Al-Bahr Pusdiklat Dewan Da'wah dengan skor 15.003, nilai mean 4,65, nilai median 5,00, dan nilai modus 5,00.
\end{abstract}

Kata kunci : persepsi masyarakat, da'wah, masjid

\section{PENDAHULUAN}

Pada masa Rasullullah masjid memiliki berbagai fungsi yang sangat banyak diantaranya fungsi ibadah, sosial, ekonomi, politik dan keamanan. Sehingga pada waktu itu, masjid memberikan banyak manfaat bagi masyarakat muslim. Sebagai contoh, Masjid Nabawi tidak kurang dari sepuluh peranan yang telah diembannya yaitu, tempat ibadah, tempat konsultasi dan komunikasi (masalah ekonomi dan sosial budaya), tempat pendidikan, tempat santunan 
sosial, tempat latihan militer dan persiapan alat-alatnya, tempat pengobatan para korban perang, tempat perdamaian dan pengadilan sengketa, aula dan tempat menerima tamu, dan pusat penerangan atau pembelaan agama. ${ }^{1}$

Masjid saat ini seharusnya memiliki fungsi sebagaimana fungsi masjid di masa Rasulullah. Namun pada realitanya para pengurus masjid belum bisa memaksimalkan fungsi masjid sebagai media da'wah dan masih banyak umat Islam yang memiliki persepsi bahwa masjid hanya sebatas tempat melaksanakan ibadah saja, dalam artian masjid hanya memiliki fungsi ibadah saja.

Dampak dari persepsi yang telah terbentuk di masyarakat tersebut, masjid menjadi kosong jika tidak ada peribadahan di dalamnya. Bahkan yang lebih mengkhawatirkan lagi pada masa sekarang orang-orang mulai menjauh dari masjid, enggan melaksanakan sholat di masjid dengan alasan "melaksanakan sholat di rumah juga bisa".

Di Indonesia, jumlah masjid yang tersebar di seluruh daerahnya tergolong sangat banyak. Menurut data Ditjen Bimas Islam Kementerian Agama yang telah mendata masjid di Indonesia secara online sejak 2013 sampai 2018 menerangkan, bahwa data masjid dan mushalla yang telah diinput melalui aplikasi SIMAS ${ }^{2}$ sebanyak 511.899. Jumlah ini terdiri dari 242.823 masjid dan 269.076 mushalla. $^{3}$

Dari jumlah masjid yang tersebar menurut data tersebut, seharusnya masyarakat Indonesia memiliki pemahaman keislaman yang bagus. Namun pada kenyataannya masjid-masjid tersebut kurang mendapat respon yang baik dari masyarakat. Mereka tidak menghiraukan keberadaan masjid, dari pada berlama-lama di masjid, mereka lebih memilih berlama-lama di tempat hiburan, tempat perbelanjaan atau tempat lainnya. Sehingga masjid menjadi kosong, bahkan jamaah sekitarpun terkadang tidak pergi ke masjid untuk melaksanakan ibadah atau kajian.

Namun dibalik kondisi kebanyakan masjid yang sepi jamaahnya, masih ada masjid-masjid yang memiliki manajemen baik dalam mengelolanya. Sehingga menghasilkan banyak program, selalu ada kegiatan di dalam masjid tersebut dan jamaah ramai hadir pada setiap kegiatan yang dilaksanakan di masjid tersebut.. Bahkan dalam pada shalat wajib lima waktu masjid selalu penuh.

Obyek penelitian ini Masjid Wadhah Abdurrahman. Al-Bahr Pusdiklat Dewan Da'wah. Masjid Al-Bahr merupakan masjid yang telah didirikan tahun 1999, namun baru dipakai untuk shalat jumat sekitar tahun 2002. Masjid yang berada

\footnotetext{
${ }^{1}$ Budiman Mustofa, Manajemen Masjid, Solo: Ziyad, 2007, Hal. 24

${ }^{2}$ Sistem informasi majid

Kemenag, https://bimasislam.kemenag.go.id/post/berita/data-masjid-danmushalla-tersedia-di-aplikasi-simas, 24 November 2018
} 
di lingkungan komplek Pusdiklat Dewan Da'wah Tambun itu berada di RT 01 RW 03, berbatasan dengan Kampung Bulu RT 03 RW 03 di sebelah barat dan perumahan Papanmas RT 01-4 RW 05 sebelah utara.

Banyak program yang telah direncanakan dan dijalankan oleh masjid $\mathrm{Al}-$ Bahr seperti kajian rutin umum, ummahat, dan remaja, belajar bahasa arab dari dasar, belajar Al-Qur'an dari dasar (anak-anak-lansia), pelayanan konsultasi syariah dan keluarga, pengurusan jenazah, ambulan gratis dan program lainnya. Dengan banyaknya program tersebut antusias masyarakat terhadap kesadaran akan pergi ke masjid semakin besar. Terbukti ketika kajian masjid selalu penuh dengan jamaah yang antusias menyimak. Begitu juga dengan shalat wajib lima waktu. Namun, menurut pengamatan penulis, yang meramaikan masjid kebanyakan warga Pusdiklat Dewan Da'wah (mahasiswa, anak-anak aitam, para asatidzah dll) sementara warga sekita tidak terlihat antusias. Jika dipresentasekan berdasarkan pengamatan peneliti selama dua bulan dari bulan Juli sampai Agustus, jumlah jama'ah yang biasa menghadiri kegiatan Masjid Al-Bahr adalah 90\% warga Pusdiklat Dewan Da'wah sementara 10\% sisanya adalah warga luar.

Berdasarkan uraian di atas, peneliti menilai masih belum tersentuhnya masyarakat sekitar oleh da'wah masjid Al-Bahr. Penulis tertarik untuk mengetahui bagaimana persepsi masyarakat terhadap da'wah yang telah dilakukan oleh masjid Al-Bahr. Untuk itu penulis berupaya mendeskripsikannya dalam sebuah karya tulis dengan judul "Persepsi Masyarakat Desa Setiamekar Bekasi Terhadap Da'wah Masjid Wadhah Abdurrahman Al-Bahr Pusdiklat Dewan Da'wah.

Dalam penelitian ini yang dimaksud masyarakat Desa Setimekar adalah seluruh masyarakat yang bertempat tinggal disana terutama masyarakat sekitar Masjid Al-Bahr. Sementara yang dimaksud Da'wah Masjid Wadhah Abdurrahman Al-Bahr Pusdiklat Dewan Da'wah adalah kegiatan-kegiatan da'wah yang dilakukan oleh masjid tersebut. Penulis melakukan pembatasan penelitian ini ditujukan supaya objek penelitian fokus pada masyarakat terdekat dengan Masjid Al-Bahr Pusdiklat Dewan Da'wah Tambun dan tema pembahasan juga fokus.

Tujuan penelitian ini adalah (1) Untuk Mengukur Seberapa Besar Persepsi Masyarakat Desa Setiamekar dari Segi Penerimaan Terhadap Da'wah Masjid Wadhah Abdurrahman Al-Bahr Pusdiklat Dewan Da'wah. (2) Untuk Mengukur Seberapa Besar Persepsi Masyarakat Desa Setiamekar dari Segi Pemahaman Terhadap Da'wah Masjid Wadhah Abdurrahman Al-Bahr Pusdiklat Dewan Da'wah (3) Untuk Mengukur Seberapa Besar Persepsi Masyarakat Desa Setiamekar dari Segi Penilaian Terhadap Da'wah Masjid Wadhah Abdurrahman Al-Bahr Pusdiklat Dewan Da'wah.

\section{Persepsi Masyarakat dan Da'wah}

Menurut Komaruddin dan Yooke Tjupamah (2000:191) Persepsi berasal dari Latin, percipere, menerima; perceptio, pengumpulan, penerimaan, pandangan, 
pengertian. 1. Kesadaran intuitif (berdasarkan filsafat) terhadap kebenaran atau kepercayan langsung terhadap sesuatu. 2. Proses dalam mengetahui obyekobyek dan peristiwa-peristiwa obyektif melalui penerapan (sensum). 3. Suatu proses psikologis yang memproduksi bayangan sehingga dapat mengenal obyek melalui berpikir asosiatif dengan cara inderawi sehingga kehadiran bayangan itu dapat disadari. Disebut juga wawasan.

Menurut Bimo Walgito, persepsi memiliki indikator-indikator sebagai berikut: (1) Penyerapan terhadap rangsangan atau objek dari luar individu. Rangsang atau objek tersebut diserap atau diterima oleh panca indera, baik penglihatan, pendengaran, peraba, pencium, dan pencecap secara sendiri-sendiri maupun bersama -sama. Dari hasil penyerapan atau penerimaan oleh alat-alat indera tersebut akan mendapatkan gambaran, tanggapan, atau kesan di dalam otak. Gambaran tersebut dapat tunggal maupun jamak, tergantung objek persepsi yang diamati. Di dalam otak terkumpul gambaran-gambaran atau kesan-kesan, baik yang lama maupun yang baru saja terbentuk. Jelas tidaknya gambaran tersebut tergantung dari jelas tidaknya rangsang, normalitas alat indera dan waktu, baru saja atau sudah lama. (2) Pengertian dan pemahaman. Setelah terjadi gambaran-gambaran atau kesan-kesan di dalam otak, maka gambaran tersebut di organisir, di klarifiksi, dibandingkan, di interpretasi, sehingga terbentuk pengertian dan pemahaman. Proses terjadinya pengertian atau pemahaman tersebut sangat unik dan cepat. Pengertian yang terbentuk tergantung juga pada gambaran-gambaran lama yang telah dimiliki individu sebelumnya disebut persepsi. (3) Penilaian atau evaluasi. Setelah terbentuk pengertian atau pemahaman, terjadilah penilaian dari individu. Individu membandingkan pengertian atau pemahaman yang baru diperoleh tersebut dengan kriteria atau norma yang dimiliki individu secara subjektif. Penilaian individu berbeda -beda meskipun objeknya sama. Oleh karena itu persepsi bersifat individual.

Dalam bahasa inggris masyarakat disebut society, berasal dari bahasa latin societas yang berasal dari kata socio artinya mengambil bagian, berbagi, menyatukan.(Lorens Bagus 2005:576). Menurut KBBI masyarakat adalah sejumlah manusia dalam arti seluas-luasnya dan terikat oleh suatu kebudayaan yang mereka anggap sama. Kelompok orang yang merasa memiliki bahasa bersama yang merasa termasuk dalam kelompok itu, atau yang berpegang pada bahasa standar yang sama.

Menurut Abu Ahmad (1997:225) masyarakat adalah golongan besar atau kecil dari beberapa manusia, yang dengan sendirinya bertalian secara golongan dan mempunyai pengaruh satu sama lain.

Menurut Abdullah (2018:4) da'wah menurut bahasa berasal dari bahasa Arab yaitu da'a, yad'uw, da'watan. Kata tersebut mempunyai makna menyeru, memanggil, mengajak dan melayani.

Dalam Kamus Besar Bahasa Indonesia (KBBI), dakwah memiliki dia makna yaitu, pertama, penyiaran, propaganda kedua penyiaran agama dan 
pengembangannya di kalangan masyarakat, seruan untuk memeluk, mempelajari, dan mengamalkan ajaran agama.

Menurut Mohammad Natsir (1999:105) da'wah adalah menyeruh manusia kepada Islam yang hanif dengan keutuhan dan keuniversalan dengan syi'ar-syi'ar dan syari'atnya dengan aqidah dankemuliaan akhlak yang unik serta cra penyampaian dengan benar.

Menurut Abdullah (2018:11) Secara bahasa da'wah mengandung makna memanggil, menyeru dan mengajak. Menurut A. Hasjmy, da'wah Islamiyah adalah mengajak orang lain untuk meyakini dan mengamalkan akidah dan syariat Islam yang terlebih dahulu telah diyakini dan diamalkan oleh penda'wah sendiri.

Menurut H.A.W Widjaja (2000:30) Akhir dari proses da'wah yang dilakukan da'i kepada mad'unya akan menghasilkan efek. Dalam komunikasi, efek merupakan salah satu dari unsur komunikasi. Sebagaimana disebutkan dalam buku ilmu komunikasi tulisan H.A.W Widjaja, unsur-unsur komunikasi terdiri dari sumber, komunikator, pesan, chanel (saluran), effect (hasil).

Menurut Andrik Purwasito (2015:245) Selain efek, akhir dari komunikasi adalah persepsi. Menurut Andrik Purwasito di dalam bukunya berjudul "Komunikasi Multikultural", persepsi adalah inti komunikasi, sedangkan penafsiran merupakan inti persepsi, identik dengan penyandian balik dalam proses komunikasi.

Menurut Suryani dan Hendryani (2016:109) Penelitian ini menggunakan pendekatan penelitian kuantitatif deskriptif. Penelitian kuantitatif merupakan penelitian yang menggunakan analisis data yang berbentuk numerik/angka.

Variabel dalam penelitian ini hanya berjumlah satu variabel atau variabel tunggal, tidak melibatkan variabel lain yang bersifat mempengaruhi atau di pengaruhi. Adapaun varibel tersebut adalah persepsi dengan tiga dimensi variabel, yaitu penerimaan, pemahaman dan penilaian sebagaimana persepsi menurut Bimo Walgito. Pengumpulan data yang digunakan pada penelitian ini menggunakan angket. Populasi dalam penelitian ini adalah seluruh masyarakat Desa Setimekar dengan jumlah 83.583 orang. Semetara itu sampel yang digunakan yaitu 396 orang. Pengujian hipotesis menggunakan bantuan program SPSS (Statistical Product and Service Solutions) for windows. Teknik analisis data yang digunakan adalah analisis data statistik deskriptif meliputi skoring, mean, median, dan modus, yang akan diuji dengan menggunakan uji validitas dan reliabitilitas.

\section{HASIL DAN PEMBAHASAN}

\section{Uji Validitas dan Reliabilitas}

Pada penelitian ini, pengujian validitas dilakukan kepada 71 responden dengan taraf signifikan 5\%, maka nilai $r$ tabel dapat dilihat menggunakan rumus sebagai berikut:

$$
\mathrm{Df}=\mathrm{N}-2
$$


$\mathrm{N}=$ Jumlah responden.

Maka Df $=71-2$

Df $=69$

Berdasarkan keterangan dengan ketentuan df (degree of freedom) yang sudah didapat yaitu $\mathrm{df}=69$ dengan taraf signifikan sebesar 5\% dan dengan melihat $\mathrm{r}$ tabel, maka dapat disimpulkan bahwa nilai $r$ tabel adalah 0,235 . Sehingga hasil uji validitas pada penelitian ini dapat dilihat dari tabel di bawah ini:

Berdasarkan hasil uji coba reliabilitas instrumen dengan menggunakan rumus Alpha yang dicari menggunakan SPSS for Windows versi 16 (Statistical Product and Service Solutions), dimana N $=71$ pada $\alpha$ kesalahan $5 \%$ diperoleh sebesar 0,746. Kemudian dikonsultasikan dengan $\mathrm{r}$ tabel sebesar 0,235 maka nilai Alpha yaitu $0,746>$ dengan $\mathrm{r}$ tabel yaitu 0,235. Maka dengan ini dinyatakan bahwa sebanyak 24 pertanyaan tersebut adalah reliabel dan dapat digunakan sebagai alat pengumpul data.

Berdasarkan hasil uji validitas dan reliabilitas diatas maka peneliti menyimpulkan bahwa semua pertanyaan dianggap valid dan reliabel. Pertanyaan-pertanyaan tersebut terdiri dari 8 pertanyaan dari segi persepsi penerimaan. 8 pertanyaan dari segi persepsi pemahaman, dan 8 pertanyaan dari segi persepsi penilaian.

\section{Deskriptif Jawaban Responden}

a. Responden masyarakat berdasarkan jenis kelamin

\begin{tabular}{|c|c|c|}
\hline Jenis Kelamin & Frekuensi & Presentasi \\
\hline Laki-laki & 172 orang & $43 \%$ \\
\hline Perempuan & 226 orang & $57 \%$ \\
\hline Jumlah & 398 orang & $100 \%$ \\
\hline
\end{tabular}

Berdasarkan data diatas menunjukkan bahwa jumlah responden laki-laki yaitu 172 orang dengan persentase sebesar $43 \%$ sedangkan Perempuan sebanyak 226 orang dengan persentase sebesar $57 \%$. Dari hasil ini dapat disimpulkan bahwa jumlah responden perempuan lebih banyak dari responden laki-laki.

\section{Deskripsi Hasil Penelitian}

Penelitian ini dilakukan di sekitar Masjid Al-Bahr Pusdiklat Dewan Da'wah Tambun yang berlokasi di Bekasi, Jawa Barat. Objek penelitian fokus pada masyarakat terdekat dengan Masjid Al-Bahr Pusdiklat Dewan Da'wah Tambun sebanyak 396 orang. Waktu pelaksanaan penelitian dilakukan pada tahun 2019.

a. Variabel Penerimaan

1) SM ( Sangat Menerima ) diberi skor 5 
2) M ( Menerima) diberi skor 4

3) KM (Kurang Menerima) diberi skor 3

4) TM ( Tidak Menerima) diberi skor 2 dan

5) STM ( Sangat Tidak Menerima) diberi skor 1.

b. Variabel Pemahaman

1) SM ( Sangat Memahami) diberi skor 5

2) $\mathrm{M}$ ( Memahami ) diberi skor 4

3) KM (Kurang Memahami) diberi skor 3

4) TM ( Tidak Memahami) diberi skor 2 dan

5) STM ( Sangat Tidak Memahami) diberi skor 1.

c. Variabel Penilaian

1) SB ( Sangat Baik) diberi skor 5

2) B ( Baik) diberi skor 4

3) KB (Kurang Baik) diberi skor 3

4) TB (Tidak Baik) diberi skor 2 dan

5) STB ( Sangat Tidak Baik) diberi skor 1.

\section{Pembahasan Hasil Penelitian}

a. Rekapitulasi Data

\begin{tabular}{|l|c|c|c|c|c|c|c|}
\hline Indikator & SM & M & KM & TM & STM & Skor & Rangking \\
\hline $\begin{array}{l}\text { Persepsi } \\
\text { Penerimaan }\end{array}$ & 7785 & 4924 & 945 & 108 & 26 & 13.788 & 2 \\
\hline $\begin{array}{l}\text { Persepsi } \\
\text { Pemahaman }\end{array}$ & 6010 & 5972 & 1158 & 140 & 33 & 13.313 & 3 \\
\hline $\begin{array}{l}\text { Persepsi } \\
\text { Penilaian }\end{array}$ & 12.035 & 2872 & 36 & 45 & 15 & 15.003 & 1 \\
\hline
\end{tabular}

Menurut Teori Bimo Walgito, bahwa reaksi tertentu akan timbul akibat stimulus tertentu sehingga seseorang dapat memberikan pendapat atau sebuah persepsi dari yang di terima oleh panca indara, baik itu berupa penglihatan, pendengaran, perasa, dan lain-lain. Menurut teori ini, persepsi terbentuk dari tiga indikator yaitu, penerimaan, pemahaman dan penilaian.

Berdasarkan skala likert diatas peneliti menyimpulkan bahwa pertanyaan mengenai persepsi penilaian mendapatkan peringkat pertama dengan skor 15.005 , pertanyaan mengenai persepsi penerimaan peringkat kedua dengan skor 13.788 dan pertanyaan mengenai persepsi pemahamman peringkat ketiga dengan skor 13.788. Sehingga peneliti menyimpulkan bahwa dak'ah Masjid Al-Bahr Pusdiklat Dewan Da'wah kepada masyarakat Desa Setiamekar memberikan dampak yang positif dari segi persepsi penilaian sesuai dengan skor yang ada.

Menurut Udin warga Rt 01/05 "Saya sudah tahu Masjid Al-bahr Dewan Da'wah sudah lama, tahu juga kegiatan-kegiatannya dan kegiatannya sangat bagus, sedikit-sedkitnya masyarakat jadi bisa ngaji”. Namun, masih ada sebagian masyarakat yang belum mengetahui kegiatan- 
kegiatan Masjid Al-Bahr menurut Teguh warga Rt 004/022 "Mas, masyarakat disini kebanyakan pendatang sehingga masih banyak masyarakat yang belum mengetahui termasuk saya sendiri. sehingga mereka juga belum paham tentang Masjid Al-Bahr Dewan Da'wah. Untuk program yang telah dijelaskan mas, sangat baik sekali, dan saya sangat mendukung. Apalagi ada program BIMBEL GRATIS"

\section{b. Nilai Rata-Rata (Mean)}

1) Nilai Rata-Rata (Mean) Penerimaan

\begin{tabular}{|c|c|c|c|}
\hline No & Indikator Pernyataan & Nilai Mean & Keterangan \\
\hline 1 & $\begin{array}{l}\text { Pengetahuan terhadap Lokasi Masjid } \\
\text { Al-Bahr Pusdiklat Dewan Da'wah }\end{array}$ & 4,75 & Sangat Positif \\
\hline 2 & $\begin{array}{l}\text { Penerimaan terhadap Informasi } \\
\text { Pelaksanaan Shalat } 5 \text { Waktu } \\
\text { Berjamaah Masjid Al-Bahr Pusdiklat } \\
\text { Dewan Da'wah }\end{array}$ & 4,64 & Sangat Positif \\
\hline 3 & $\begin{array}{l}\text { Penerimaan terhadap Informasi } \\
\text { Pelaksanaan Sholat Jum'at Masjid } \\
\text { Al-Bahr Pusdiklat Dewan Da'wah }\end{array}$ & 4,65 & Sangat Positif \\
\hline 4 & $\begin{array}{l}\text { Penerimaan terhadap Informasi } \\
\text { Pelaksanaan Sholat Idhul Fitri } \\
\text { Masjid Al-Bahr Pusdiklat Dewan } \\
\text { Da'wah }\end{array}$ & 4,68 & Sangat Positif \\
\hline 5 & $\begin{array}{l}\text { Penerimaan terhadap Informasi } \\
\text { Program Kajian Rutin Umum, } \\
\text { Ummahat Dan Remaja Masjid Al- } \\
\text { Bahr Pusdiklat Dewan Da'wah }\end{array}$ & 4,20 & Positif \\
\hline 6 & $\begin{array}{l}\text { Penerimaan terhadap Informasi } \\
\text { Program Pengurusan Jenazah dan } \\
\text { Ambulance Masjid Al-Bahr } \\
\text { Pusdiklat Dewan Da'wah }\end{array}$ & 4,05 & Positif \\
\hline 7 & $\begin{array}{l}\text { Penerimaan terhadap Informasi } \\
\text { Pelaksanaan Qurban Masjid Al-Bahr } \\
\text { Pusdiklat Dewan Da'wah }\end{array}$ & 4,51 & Sangat Positif \\
\hline 8 & $\begin{array}{l}\text { Penerimaan terhadap Program } \\
\text { BIMBEL GRATIS untuk anak dan } \\
\text { remaja Al-Bahr Pusdiklat Dewan } \\
\text { Da'wah }\end{array}$ & 3,16 & Kurang Positif \\
\hline & Total & 34,64 & Sangat Positif \\
\hline
\end{tabular}

Dari tabel di atas dapat di lihat bahwa skor rata-rata (mean) pemahaman akhir dari keseluruhan data yang diperoleh adalah sejumlah $34,64: 8=4,58$ yang berada pada skala interval 4,25 - 5,04 atau 
kategori sangat positif. Maka dari pengolahan data tersebut dapat disimpulkan bahwa Persepsi Masyarakat Masyarakat Desa Setiamekar dari segi pemahaman terhadap Da'wah Masjid Wadhah Abdurrahman Al-Bahr Pusdiklat Dewan Da'wah sangat positif.

\section{2) Nilai Rata-Rata (Mean) Pemahaman}

\begin{tabular}{|c|c|c|c|}
\hline No & Indikator Pernyataan & Nilai Mean & Keterangan \\
\hline 1 & $\begin{array}{l}\text { Pemahaman terhadap Lokasi Masjid } \\
\text { Al-Bahr Pusdiklat Dewan Da'wah }\end{array}$ & 4,65 & Sangat Positif \\
\hline 2 & $\begin{array}{l}\text { Pemahaman terhadap Informasi } \\
\text { Pelaksanaan Shalat } 5 \text { Waktu } \\
\text { Berjamaah Masjid Al-Bahr Pusdiklat } \\
\text { Dewan Da'wah }\end{array}$ & 4,35 & Sangat Positif \\
\hline 3 & $\begin{array}{l}\text { Pemahaman terhadap Informasi } \\
\text { Pelaksanaan Sholat Jum'at Masjid } \\
\text { Al-Bahr Pusdiklat Dewan Da'wah }\end{array}$ & 4,59 & Sangat Positif \\
\hline 4 & $\begin{array}{l}\text { Pemahaman terhadap Informasi } \\
\text { Pelaksanaan Sholat Idhul Fitri } \\
\text { Masjid Al-Bahr Pusdiklat Dewan } \\
\text { Da'wah }\end{array}$ & 4,39 & Sangat Positif \\
\hline 5 & $\begin{array}{l}\text { Pemahaman terhadap Informasi } \\
\text { Program Kajian Rutin Umum, } \\
\text { Ummahat Dan Remaja Masjid Al- } \\
\text { Bahr Pusdiklat Dewan Da'wah }\end{array}$ & 4,09 & Positif \\
\hline 6 & $\begin{array}{l}\text { Pemahaman terhadap Informasi } \\
\text { Program Pengurusan Jenazah dan } \\
\text { Ambulance Masjid Al-Bahr } \\
\text { Pusdiklat Dewan Da'wah }\end{array}$ & 3,98 & Positif \\
\hline 7 & $\begin{array}{l}\text { Pemahaman terhadap Informasi } \\
\text { Pelaksanaan Qurban Masjid Al-Bahr } \\
\text { Pusdiklat Dewan Da'wah }\end{array}$ & 4,39 & Sangat Positif \\
\hline 8 & $\begin{array}{l}\text { Pemahaman terhadap Program } \\
\text { BIMBEL GRATIS untuk anak dan } \\
\text { remaja Al-Bahr Pusdiklat Dewan } \\
\text { Da'wah }\end{array}$ & 2,98 & Sedang \\
\hline & Total & 33,45 & Positif \\
\hline
\end{tabular}

Dari tabel di atas dapat di lihat bahwa skor rata-rata (mean) pemahaman akhir dari keseluruhan data yang diperoleh adalah sejumlah 33,45: $8=4,18$ yang berada pada skala interval 3,43 - 4,23 atau kategori positif. Maka dari pengolahan data tersebut dapat disimpulkan bahwa Persepsi Masyarakat Masyarakat Desa Setiamekar dari segi pemahaman 
terhadap Da'wah Masjid Wadhah Abdurrahman Al-Bahr Pusdiklat Dewan Da'wah positif.

\section{3) Nilai Rata-Rata (Mean) Penilaian}

\begin{tabular}{|c|c|c|c|}
\hline No & Indikator Pernyataan & Nilai Mean & Keterangan \\
\hline 1 & $\begin{array}{l}\text { Dukungan terhadap Lokasi Masjid } \\
\text { Al-Bahr Pusdiklat Dewan Da'wah }\end{array}$ & 4,77 & Sangat Positif \\
\hline 2 & $\begin{array}{l}\text { Dukungan terhadap Informasi } \\
\text { Pelaksanaan Shalat } 5 \text { Waktu } \\
\text { Berjamaah Masjid Al-Bahr Pusdiklat } \\
\text { Dewan Da'wah }\end{array}$ & 4.75 & Sangat Positif \\
\hline 3 & $\begin{array}{l}\text { Dukungan terhadap Informasi } \\
\text { Pelaksanaan Sholat Jum'at Masjid } \\
\text { Al-Bahr Pusdiklat Dewan Da'wah }\end{array}$ & 4,76 & Sangat Positif \\
\hline 4 & $\begin{array}{l}\text { Dukungan terhadap Informasi } \\
\text { Pelaksanaan Sholat Idhul Fitri } \\
\text { Masjid Al-Bahr Pusdiklat Dewan } \\
\text { Da'wah }\end{array}$ & 4,72 & Sangat Positif \\
\hline 5 & $\begin{array}{l}\text { Dukungan terhadap Informasi } \\
\text { Program Kajian Rutin Umum, } \\
\text { Ummahat Dan Remaja Masjid Al- } \\
\text { Bahr Pusdiklat Dewan Da'wah }\end{array}$ & 4,70 & Sangat Positif \\
\hline 6 & $\begin{array}{l}\text { Dukungan terhadap Informasi } \\
\text { Program Pengurusan Jenazah dan } \\
\text { Ambulance Masjid Al-Bahr } \\
\text { Pusdiklat Dewan Da'wah }\end{array}$ & 4,63 & Sangat Positif \\
\hline 7 & $\begin{array}{l}\text { Dukungan terhadap Informasi } \\
\text { Pelaksanaan Qurban Masjid Al-Bahr } \\
\text { Pusdiklat Dewan Da'wah }\end{array}$ & 4,69 & Sangat Positif \\
\hline 8 & $\begin{array}{l}\text { Dukungan terhadap Program } \\
\text { BIMBEL GRATIS untuk anak dan } \\
\text { remaja Al-Bahr Pusdiklat Dewan } \\
\text { Da'wah }\end{array}$ & 4,69 & Sangat Positif \\
\hline & Total & 37,70 & Sangat Positif \\
\hline
\end{tabular}

Dari tabel di atas dapat di lihat bahwa skor rata-rata (mean) penilaian akhir dari keseluruhan data yang diperoleh adalah sejumlah $37,70: 8=4,71$ yang berada pada skala interval 4,25 - 5,04 atau berkategori sangat positif. Maka dari pengolahan data tersebut dapat disimpulkan bahwa Persepsi dari segi penilaian Masyarakat Desa Setiamekar terhadap Da'wah Masjid Wadhah Abdurrahman Al-Bahr Pusdiklat Dewan Da'wah sangat positif. 
c. Nilai Tengah (Median) dan Modus

1) NIlai Tengah (Median) dan Modus Penerimaan

\begin{tabular}{|c|c|c|c|}
\hline No & Indikator Pernyataan & $\begin{array}{c}\text { Nilai } \\
\text { Median }\end{array}$ & Nilai Modus \\
\hline 1 & $\begin{array}{l}\text { Pengetahuan terhadap Lokasi Masjid } \\
\text { Al-Bahr Pusdiklat Dewan Da'wah }\end{array}$ & 5,00 & 5 \\
\hline 2 & $\begin{array}{l}\text { Penerimaan terhadap Informasi } \\
\text { Pelaksanaan Shalat } 5 \text { Waktu } \\
\text { Berjamaah Masjid Al-Bahr Pusdiklat } \\
\text { Dewan Da'wah }\end{array}$ & 5,00 & 5 \\
\hline 3 & $\begin{array}{l}\text { Penerimaan terhadap Informasi } \\
\text { Pelaksanaan Sholat Jum'at Masjid } \\
\text { Al-Bahr Pusdiklat Dewan Da'wah }\end{array}$ & 5,00 & 5 \\
\hline 4 & $\begin{array}{l}\text { Penerimaan terhadap Informasi } \\
\text { Pelaksanaan Sholat Idhul Fitri } \\
\text { Masjid Al-Bahr Pusdiklat Dewan } \\
\text { Da'wah }\end{array}$ & 5,00 & 5 \\
\hline 5 & $\begin{array}{l}\text { Penerimaan terhadap Informasi } \\
\text { Program Kajian Rutin Umum, } \\
\text { Ummahat Dan Remaja Masjid Al- } \\
\text { Bahr Pusdiklat Dewan Da'wah }\end{array}$ & 4,00 & 4 \\
\hline 6 & $\begin{array}{l}\text { Penerimaan terhadap Informasi } \\
\text { Program Pengurusan Jenazah dan } \\
\text { Ambulance Masjid Al-Bahr } \\
\text { Pusdiklat Dewan Da'wah }\end{array}$ & 4,00 & 4 \\
\hline 7 & $\begin{array}{l}\text { Penerimaan terhadap Informasi } \\
\text { Pelaksanaan Qurban Masjid Al-Bahr } \\
\text { Pusdiklat Dewan Da'wah }\end{array}$ & 5,00 & 5 \\
\hline 8 & $\begin{array}{l}\text { Penerimaan terhadap Program } \\
\text { BIMBEL GRATIS untuk anak dan } \\
\text { remaja Al-Bahr Pusdiklat Dewan } \\
\text { Da'wah }\end{array}$ & 3,00 & 3 \\
\hline & Total & 36,00 & 36 \\
\hline
\end{tabular}

Setelah peneliti menggunakan SPSS untuk mencari nilai median dan modus dari data di atas, maka hasil yang didapatkan untuk nilai median dan modus Persepsi dari segi Penerimaan Masyarakat Desa Setiamekar terhadap Da'wah Masjid Wadhah Abdurrahman Al-Bahr Pusdiklat Dewan Da'wah adalah 5,00 (Sangat Positif) dan 5 (Sangat Positif)

2) Nilai Tengah (Median) dan Modus Pemahaman

\begin{tabular}{|c|c|c|c|}
\hline No & Indikator Pernyataan & $\begin{array}{c}\text { Nilai } \\
\text { Median }\end{array}$ & Nilai Modus \\
\hline
\end{tabular}




\begin{tabular}{|c|l|c|c|}
\hline $\mathbf{1}$ & $\begin{array}{l}\text { Pemahaman terhadap Lokasi Masjid } \\
\text { Al-Bahr Pusdiklat Dewan Da'wah }\end{array}$ & 5,00 & 5 \\
\hline $\mathbf{2}$ & $\begin{array}{l}\text { Pemahaman terhadap Informasi } \\
\text { Pelaksanaan Shalat 5 Waktu } \\
\text { Berjamaah Masjid Al-Bahr Pusdiklat } \\
\text { Dewan Da'wah }\end{array}$ & 4,00 & 5 \\
\hline $\mathbf{3}$ & $\begin{array}{l}\text { Pemahaman terhadap Informasi } \\
\text { Pelaksanaan Sholat Jum'at Masjid } \\
\text { Al-Bahr Pusdiklat Dewan Da'wah }\end{array}$ & 5,00 & 4 \\
\hline $\mathbf{4}$ & $\begin{array}{l}\text { Pemahaman terhadap Informasi } \\
\text { Pelaksanaan Sholat Idhul Fitri } \\
\text { Masjid Al-Bahr Pusdiklat Dewan } \\
\text { Da'wah }\end{array}$ & $\begin{array}{l}\text { Pemahaman terhadap Informasi } \\
\text { Program Kajian Rutin Umum, } \\
\text { Ummahat Dan Remaja Masjid Al- } \\
\text { Bahr Pusdiklat Dewan Da'wah }\end{array}$ \\
\hline $\mathbf{6}$ & $\begin{array}{l}\text { Pemahaman terhadap Informasi } \\
\text { Program Pengurusan Jenazah dan } \\
\text { Ambulance Masjid Al-Bahr } \\
\text { Pusdiklat Dewan Da'wah }\end{array}$ & 4,00 \\
\hline $\mathbf{7}$ & $\begin{array}{l}\text { Pemahaman terhadap Informasi } \\
\text { Pelaksanaan Qurban Masjid Al-Bahr } \\
\text { Pusdiklat Dewan Da'wah }\end{array}$ & 4,00 & 4 \\
\hline $\mathbf{8}$ & $\begin{array}{l}\text { Pemahaman terhadap Program } \\
\text { BIMBEL GRATIS untuk anak dan } \\
\text { remaja Al-Bahr Pusdiklat Dewan } \\
\text { Da'wah }\end{array}$ & 4,00 & 3 \\
\hline & \begin{tabular}{l} 
Total \\
\hline
\end{tabular} & 34,00 & 3 \\
\hline
\end{tabular}

Setelah peneliti menggunakan SPSS untuk mencari nilai median dan modus dari data di atas, maka hasil yang didapatkan untuk nilai median dan modus Persepsi dari segi Pemahaman Masyarakat Desa Setiamekar terhadap Da'wah Masjid Wadhah Abdurrahman Al-Bahr Pusdiklat Dewan Da'wah adalah 4,00 (Positif) dan 4 (Positif).

3) Nilai Tengah (Median) dan Modus Penilaian

\begin{tabular}{|c|l|c|c|}
\hline No & \multicolumn{1}{|c|}{ Indikator Pernyataan } & $\begin{array}{c}\text { Nilai } \\
\text { Median }\end{array}$ & $\begin{array}{c}\text { Nilai } \\
\text { Modus }\end{array}$ \\
\hline $\mathbf{1}$ & $\begin{array}{l}\text { Dukungan terhadap Lokasi } \\
\text { Masjid Al-Bahr Pusdiklat Dewan } \\
\text { Da'wah }\end{array}$ & 5,00 & 5 \\
\hline $\mathbf{2}$ & Dukungan terhadap Informasi & 5,00 & 5 \\
\hline
\end{tabular}




\begin{tabular}{|c|l|c|c|}
\hline $\mathbf{3}$ & $\begin{array}{l}\text { Pelaksanaan Shalat 5 Waktu } \\
\text { Berjamaah Masjid Al-Bahr } \\
\text { Pusdiklat Dewan Da'wah }\end{array}$ & $\begin{array}{l}\text { Pukungan terhadap Informasi } \\
\text { Pelaksanaan Sholat Jum'at } \\
\text { Masjid Al-Bahr Pusdiklat Dewan } \\
\text { Da'wah }\end{array}$ & 5,00 \\
\hline $\mathbf{4}$ & $\begin{array}{l}\text { Dukungan terhadap Informasi } \\
\text { Pelaksanaan Sholat Idhul Fitri } \\
\text { Masjid Al-Bahr Pusdiklat Dewan } \\
\text { Da'wah }\end{array}$ & 5,00 & 5 \\
\hline $\mathbf{5}$ & $\begin{array}{l}\text { Dukungan terhadap Informasi } \\
\text { Program Kajian Rutin Umum, } \\
\text { Ummahat Dan Remaja Masjid } \\
\text { Al-Bahr Pusdiklat Dewan Da'wah }\end{array}$ & $\begin{array}{l}\text { Dukungan terhadap Informasi } \\
\text { Program Pengurusan Jenazah dan } \\
\text { Ambulance Masjid Al-Bahr } \\
\text { Pusdiklat Dewan Da'wah }\end{array}$ & 5,00 \\
\hline $\mathbf{7}$ & $\begin{array}{l}\text { Dukungan terhadap Informasi } \\
\text { Pelaksanaan Qurban Masjid Al- } \\
\text { Bahr Pusdiklat Dewan Da'wah }\end{array}$ & 5,00 & 5 \\
\hline $\mathbf{8}$ & $\begin{array}{l}\text { Dukungan terhadap Program } \\
\text { BIMBEL GRATIS untuk anak } \\
\text { dan remaja Al-Bahr Pusdiklat } \\
\text { Dewan Da'wah }\end{array}$ & 5,00 & 5 \\
\hline & \begin{tabular}{l} 
Total \\
\hline
\end{tabular} & 39,00 & 50 \\
\hline
\end{tabular}

Setelah peneliti menggunakan SPSS untuk mencari nilai median dan modus dari data di atas, maka hasil yang didapatkan untuk nilai median dan modus Persepsi dari segi Penilaian Masyarakat Desa Setiamekar terhadap Da'wah Masjid Wadhah Abdurrahman Al-Bahr Pusdiklat Dewan Da'wah adalah 5,00 (Sangat Positif) dan 5 (Sangat Positif)

\section{PENUTUP}

a. Berdasarkan data hasil penelitian, maka terdapat persepsi sangat positif dari segi penerimaan Masyarakat Desa Setiamekar terhadap Da'wah Masjid Wadhah Abdurrahman Al-Bahr Pusdiklat Dewan Da'wah dengan nilai skor 13.788, mean 4,28, nilai median 5,00, dan nilai modus 5 , sedangkan dari segi pemahaman Masyarakat Desa Setiamekar terhadap Da'wah Masjid Wadhah Abdurrahman Al-Bahr 
Pusdiklat Dewan Da'wah dengan skor 13.313, mean 4,1, nilai median 4,00, dan nilai modus 4, dan dari segi penilaian Masyarakat Desa Setiamekar terhadap Da'wah Masjid Wadhah Abdurrahman Al-Bahr Pusdiklat Dewan Da'wah dengan skor 15.003, nilai mean 4,65, nilai median 5,00, dan nilai modus 5,00.

b. Perlu adanya sosialisasi yang menyentuh langsung masyarakat sekitar Masjid Al-Bahr Pusdiklat Dewan Da'wah. Karena masih ada sebagian kecil masyarakat yang belum mengetahui programprogramnya, membuat tabligh akbar, melakukan penyuluhan keagamaan ke rumah-rumah warga minimal setiap bulan sekali dengan mengerahkan da'i yang ada

c. Menyertakan masyarakat sekitar Masjid Al-Bahr Pusdiklat Dewan Da'wah setiap ada kegiatan atau bahkan kepengurusan supaya da'wah akan lebih mudah menyebar di lingkungan tersebut.

\section{DAFTAR PUSTAKA}

Abdullah. (2018). Ilmu Dakwah Kajian Ontologi, Epistimologi, Aksiologi dan Aplikasi Dakwah, Depok: Rajawali Pers

H.A.W. Widjaja. (2000). Ilmu Komunikasi Pengantar Studi, Jakarta: Rineka Cipta

Andrik Purwasito. (2015.) Komunikasi Multikultural, Yogyakarta: Pustaka Pelajar

Komaruddin dan Yooke Tjuparmah S. Komaruddin, Kamus Istilah Karya Tulis Ilmiah, Jakarta: Bumi Aksara, 2000, Cet. 1, Hal. 191

Lorens Bagus. (2005). Kamus Filsafat, Jakarta: Gramedia

Tim Penyusun Kamus Pembinaan dan Pengembangan Bahasa, Kamus Besar Bahasa Indonesia

Abu Ahmad. (1997) Ilmu Sosial Dasar, Jakarta: Rieneke Cipta, 1997

Abdullah. (2018). Ilmu Da'wah: Kajian Ontologi, Epistimologi, Aksiologi, dan Aplikasi Da'wah, Depok: Rajawali Pers

Mohammad Natsir. (1999). Fiqbu Da'wah Jakarta: Media Da'wah

Suryani dan Hendryadi. (2016). Metode Riset Kuantitatif Teori dan Aplikasi Pada Penelitian Bidang Manajemen dan Ekonomi Islam, Jakarta: Prenadamedia Group 